\title{
Remote Ischemic Preconditioning Reduces the Risk of Contrast-Induced Nephropathy in Patients with Moderate Renal Impairment Undergoing Percutaneous Coronary Angiography: A Meta-Analysis
}

\author{
Jin Deng ${ }^{a} \mathrm{Yi} \mathrm{Lu}^{\mathrm{a}}$ Jihong Ou ${ }^{\mathrm{a}}$ Xiaofei Shao ${ }^{\mathrm{b}}$ Xin Wang ${ }^{\mathrm{b}}$ \\ Hongping Xie ${ }^{a}$ \\ aDepartment of Nephrology, The First Affiliated Hospital of University of South China, \\ Hengyang, China; ${ }^{b}$ Department of Nephrology, The Third Affiliated Hospital of Southern \\ Medical University, Guangzhou, China
}

\section{Keywords}

Remote ischemic preconditioning · Contrast-induced nephropathy · Meta-analysis

\begin{abstract}
Background/Aims: This meta-analysis evaluated the effects of remote ischemic preconditioning (RIPC) on the risk of contrast-induced nephropathy $(\mathrm{CIN})$ in patients undergoing percutaneous coronary intervention/coronary angiography (PCl/CA). Methods: PubMed, Embase, and the Cochrane Central Register of Controlled Trials databases were searched for randomized controlled trials (RCTs) that assessed the effect of RIPC on CIN in patients undergoing PCI/CA. The main outcomes of interest were the incidence of CIN 48-72 h after CA, the levels of serum creatinine, cystatin $C$, neutrophil gelatinase-associated lipocalin, and estimated glomerular filtration rate (eGFR), mortality, and requirement of hemodialysis and rehospitalization. The analysis was conducted using the random-effect model due to the expected heterogeneity among different studies. Results: In total, 16 trials covering 2,048 patients were identified. By assessing the methodological quality of the included studies through the Cochrane risk of bias, we found that of the 16 RCTs, 3 had a low risk of bias, 6 a high, and 7 an unclear risk. The application of RIPC decreased the incidence of CIN (relative risk, RR, $0.50,95 \%$ confidence interval, $\mathrm{Cl}, 0.39-0.65 ; p<0.001)$. Subgroup analyses showed that RIPC decreased the incidence of $\mathrm{CIN}$ in patients with eGFR $<60 \mathrm{~mL} / \mathrm{min} / 1.73 \mathrm{~m}^{2}$ (RR 0.53, 95\% Cl 0.38-0.75;
\end{abstract}

J.D. and Y.L. contributed equally to this work, and they are both first authors. 


\section{Kidney \\ Blood Pressure \\ Research}

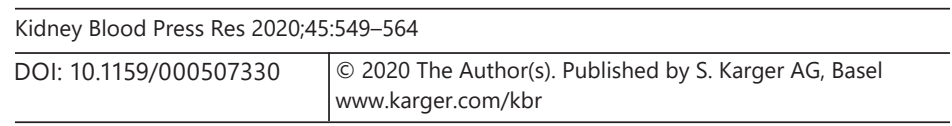

Deng et al.: Remote Ischemic Preconditioning Prevents Contrast-Induced Nephropathy

$p<0.001)$ but not in patients with eGRF $\geq 60 \mathrm{~mL} / \mathrm{min} / 1.73 \mathrm{~m}^{2}$ (RR $0.82,95 \% \mathrm{Cl} 0.35-1.94 ; p=$ $0.66)$ at baseline. Furthermore, the increase in serum creatinine was significantly lower in patients with RIPC compared to control patients (standardized mean difference $-1.41,95 \% \mathrm{Cl}$ -2.46 to $-0.35 ; p=0.009$ ). Conclusions: Based on 16 RCTs, this meta-analysis shows that RIPC can reduce the risk of $\mathrm{CIN}$ in patients with moderate renal impairment undergoing $\mathrm{PCI} / \mathrm{CA}$. However, this needs to be confirmed by further high-quality evidence.

(C) 2020 The Author(s)

Published by S. Karger AG, Basel

\section{Introduction}

In recent years, the number of percutaneous procedures requiring contrast medium administration has increased exponentially [1]. Contrast-induced nephropathy (CIN) is a common iatrogenic complication of percutaneous coronary intervention (PCI)/coronary angiography (CA), and it is associated with poor cardiovascular and renal outcomes [2,3]. The most common definitions of CIN in use are an absolute rise of $>0.5 \mathrm{mg} / \mathrm{dL}$ and/or a relative increase of $>25 \%$ in serum creatinine compared with baseline within 48-72 h after contrast administration without an alternative cause of kidney injury [4]. The incidence of CIN varies from $2 \%$ in the general population to $\geq 50 \%$ in high-risk groups [5]. Clinical surveys have revealed that patients with renal dysfunction are more likely to develop CIN compared to those with normal renal function. Several concomitant risk factors such as old age, diabetes, congestive heart failure, hypertension as well as the type and amount of the contrast agent contribute to the occurrence of CIN [6-8]. As the third most common cause of acute kidney injury (AKI), CIN has been closely linked with the need for dialysis and intensive care unit support, prolonged hospital stay, and significant mortality [9]. There are 2 main pathways to prevent CIN: optimal hydration and use of lower volumes of contrast medium. $\mathrm{N}$-acetylcysteine was probably the most investigated adjunctive therapy, so far failing to prove a significant clinical benefit of preventing CIN [10-13].

Remote ischemic preconditioning (RIPC) seeks to stimulate endogenous protective mechanisms by inducing short intermittent periods of ischemic reperfusion by blocking blood flow in nontarget tissues such as limbs before subsequent episodes of ischemia-reperfusion injury [14, 15]. In 1993, Przyklenk et al. [16] found that preconditioning of the heart confers protection not only to coronary perfusion vessels, but also to remote tissues. Since then, several studies have demonstrated that ischemic preconditioning can protect distal organs or tissues, such as the kidney, small intestine and extremities [17-19]. Therefore, it can be used to protect vital organs that are susceptible to ischemic damage [20]. In recent years, RIPC has emerged as a novel nonpharmacological approach used to prevent CIN. Given that findings from previous investigation on the use of RIPC on CIN have been inconsistent, we designed this meta-analysis to provide a more comprehensive analysis of the previous literature and to determine whether RIPC confers protection to patients undergoing PCI/CA.

\section{Materials and Methods}

Criteria for Study Inclusion

The Preferred Reporting Items for Systematic Reviews and Meta-Analyses (PRISMA) guidelines were followed in this study [21]. All studies that met the following criteria were included: (i) only randomized controlled trials (RCTs) were enrolled; (ii) the studies 


\section{Kidney \\ Blood Pressure \\ Research}

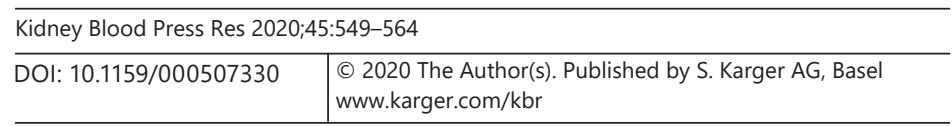

Deng et al.: Remote Ischemic Preconditioning Prevents Contrast-Induced Nephropathy

contained patients undergoing PCI or CA; (iii) patients were randomized to receive RIPC or sham RIPC therapy; (iv) at least one of the following was reported: the incidence of CIN, the levels of serum creatinine, cystatin C, neutrophil gelatinase-associated lipocalin (NGAL), or estimated glomerular filtration rate (eGFR), mortality, and requirement of hemodialysis and rehospitalization. Studies were excluded if the patients received postischemic conditioning.

\section{Search Strategy}

We conducted a literature search on Pubmed, Embase, and Cochrane Central Register of Controlled Trials. The search keywords were: "remote ischemic preconditioning," "ischemic preconditioning," "ischemic conditioning," "acute kidney injuries," "acute renal injury," "acute kidney failure," "acute renal failure," "acute renal insufficiency," "acute kidney insufficiency," and "contrast induced nephropathy." Search strategies are listed in online supplement 1 (for all online suppl. material, see www.karger.com/doi/10.1159/000507330). We scrutinized the reference lists of all included articles to identify additional studies.

\section{Study Selection and Data Extraction}

By examining the titles and/or abstracts of all studies, studies that did not meet the inclusion criteria were excluded. The full texts of studies that met the inclusion criteria were reviewed. The following information was extracted: baseline characteristics, patient information, intervention treatment, and the dose of contrast agent. Also, we extracted outcome data such as the incidence of CIN (as defined in Table 1), the levels of serum creatinine, eGFR, NGAL, and cystatin C, and clinical adverse results (the number of hemodialyses, rehospitalization, and mortality).

\section{Assessment of Risk of Bias}

The Cochrane handbook was used to assess the quality of the included studies under the following 6 criteria: (1) adequate sequence generation; (2) allocation concealment; (3) blinding; (4) incomplete outcome data; (5) selective reporting; (6) other bias. These criteria were graded as low, high, or unclear risk of bias according to the text. We inferred that the unclear risk of bias implied that there was no information or uncertainty on the potential of bias. Studies were considered to have a high risk of bias if they contained one criterion classified as high risk of bias; studies were considered to have a low risk of bias only if all criteria had a low risk of bias; studies were rated to have an unclear risk of bias if there was at least one criterion that was viewed as unclear risk of bias and without high risk.

\section{Statistical Analysis}

Relative risk (RR), such as the incidence of CIN, was used to report dichotomous data, while standardized mean difference (SMD) with 95\% confidence interval (CI) was used to report continuous outcomes such as eGFR, serum creatinine, NGAL, and cystatin C. The analysis was conducted using the random-effect model due to the expected heterogeneity among different studies. Since eGFR $<60 \mathrm{~mL} / \mathrm{min} / 1.73 \mathrm{~m}^{2}$ is a risk factor for CIN, we conducted a subgroup analysis based on baseline eGRF. Given that the measurement time varied in included RCTs, we conducted a subgroup analysis based on measurement time $<48$ or $\geq 48 \mathrm{~h}$ after PCI/CA. Since the definition of CIN was inconsistent in the included studies, we performed a sensitivity analysis to confirm the effects of different definitions of CIN on the results. Meanwhile, funnel plots were used to explore publication bias if 10 or more studies were included. 
Table 1. Baseline characteristics of included studies

\begin{tabular}{|c|c|c|c|c|c|c|}
\hline Study & $\begin{array}{l}\text { Inclusion } \\
\text { criteria }\end{array}$ & $\begin{array}{l}\text { Number } \\
\text { involved, R/C }\end{array}$ & Sex, M/F & $\begin{array}{l}\text { Age, } \\
\text { years }\end{array}$ & $\begin{array}{l}\text { eGFR, } \\
\mathrm{mL} / \mathrm{min} / 1.73 \mathrm{~m}^{2}\end{array}$ & $\begin{array}{l}\text { Serum creatinine, } \\
\mathrm{mg} / \mathrm{dL}\end{array}$ \\
\hline Hoole et al. [24], 2009 & PCI & $104 / 98$ & $\begin{array}{l}\text { R: } 84 / 20 \\
\text { C: } 74 / 24\end{array}$ & $\begin{array}{l}\text { R: } 63.2 \pm 10.1 \\
\text { C: } 61.8 \pm 10.3\end{array}$ & - & - \\
\hline Balbir Singh et al. [15], 2016 & PCI & $51 / 51$ & $\begin{array}{l}R: 23 / 28 \\
C: 25 / 26\end{array}$ & $\begin{array}{l}R: 67.8 \pm 7.6 \\
C: 69.0 \pm 8.6\end{array}$ & $\begin{array}{l}R: 48.5 \pm 12.0 \\
C: 46.6 \pm 10.2\end{array}$ & $\begin{array}{l}\mathrm{R}: 1.42 \pm 0.58 \\
\mathrm{C}: 1.41 \pm 0.34\end{array}$ \\
\hline Xu et al. [31], 2014 & PCI & $102 / 98$ & $\begin{array}{l}\mathrm{R}: 68 / 34 \\
\mathrm{C}: 68 / 30\end{array}$ & $\begin{array}{l}R: 69.1 \pm 3.8 \\
C: 68.9 \pm 2.9\end{array}$ & $\begin{array}{l}\text { R: } 99.1 \pm 20.6 \\
\text { C: } 100.8 \pm 28.2\end{array}$ & $\begin{array}{l}\text { R: } 0.88 \pm 0.19 \\
\text { C: } 0.84 \pm 0.20\end{array}$ \\
\hline Luo et al. [26], 2013 & PCI & $101 / 104$ & $\begin{array}{l}\text { R: } 78 / 23 \\
\text { C: } 78 / 26\end{array}$ & $\begin{array}{l}\text { R: } 59.2 \pm 10.3 \\
C: 59.3 \pm 9.5\end{array}$ & $\begin{array}{l}\mathrm{R}: 101 \pm 20 \\
\mathrm{C}: 100 \pm 20\end{array}$ & - \\
\hline Er et al. [18], 2012 & CA & $50 / 50$ & $\begin{array}{l}\mathrm{R}: 34 / 16 \\
\mathrm{C}: 37 / 13\end{array}$ & $\begin{array}{l}\text { R: } 73.2 \pm 9.1 \\
\text { C: } 72.7 \pm 11.4\end{array}$ & $\begin{array}{l}R: 40.6 \pm 8.7 \\
C: 41.3 \pm 11.9\end{array}$ & $\begin{array}{l}\text { R: } 1.63(1.47-1.81) \\
\text { C: } 1.62(1.39-1.93)\end{array}$ \\
\hline Igarashi et al. [25], 2013 & PCI or CA & $30 / 30$ & $\begin{array}{l}\text { R: } 20 / 10 \\
\text { C: } 23 / 7\end{array}$ & $\begin{array}{l}\mathrm{R}: 71.3 \pm 8.1 \\
\mathrm{C}: 70.8 \pm 7.6\end{array}$ & $\begin{array}{l}\mathrm{R}: 47.4 \pm 9.4 \\
\mathrm{C}: 48.9 \pm 6.0\end{array}$ & $\begin{array}{l}\mathrm{R}: 1.15 \pm 0.29 \\
\mathrm{C}: 1.12 \pm 0.17\end{array}$ \\
\hline Savaj et al. [28], 2014 & $\mathrm{CA}$ & $48 / 48$ & $\begin{array}{l}\text { R: } 17 / 31 \\
\mathrm{C}: 14 / 34\end{array}$ & $\begin{array}{l}R: 63.0 \pm 8.9 \\
C: 60.9 \pm 9.6\end{array}$ & $\begin{array}{l}\mathrm{R}: 78.2 \pm 25.8 \\
\mathrm{C}: 94.7 \pm 40.2\end{array}$ & $\begin{array}{l}\text { R: } 1.3 \pm 0.4 \\
\text { C: } 1.1 \pm 0.3\end{array}$ \\
\hline Yamanaka et al. [32], 2015 & PCI & $47 / 47$ & $\begin{array}{l}\text { R: } 34 / 13 \\
\text { C: } 36 / 11\end{array}$ & $\begin{array}{l}\text { R: } 67.0 \pm 12.0 \\
\text { C: } 67.0 \pm 15.0\end{array}$ & $\begin{array}{l}\text { R: } 73.0 \pm 20.0 \\
\text { C: } 79.0 \pm 33.0\end{array}$ & $\begin{array}{l}\text { R: } 0.82 \pm 0.21 \\
\text { C: } 0.87 \pm 0.44\end{array}$ \\
\hline Zagidullin et al. [33], 2017 & $\mathrm{CA}$ & $26 / 25$ & $\begin{array}{l}\mathrm{R}: 21 / 5 \\
\mathrm{C}: 22 / 3\end{array}$ & $\begin{array}{l}R: 60.5 \pm 1.95 \\
C: 62.96 \pm 1.72\end{array}$ & - & $\begin{array}{l}\mathrm{R}: 1.41 \pm 0.13 \\
\mathrm{C}: 1.21 \pm 0.11\end{array}$ \\
\hline Zhou et al. [34], 2018 & PCI & $50 / 57$ & $\begin{array}{l}\text { R: } 30 / 20 \\
\text { C: } 35 / 22\end{array}$ & $\begin{array}{l}\mathrm{R}: 69.42 \pm 7.07 \\
\mathrm{C}: 69.14 \pm 7.80\end{array}$ & $\begin{array}{l}R: 69.99 \pm 8.91 \\
\text { C: } 68.02 \pm 10.17\end{array}$ & $\begin{array}{l}\mathrm{R}: 1.02 \pm 0.20 \\
\mathrm{C}: 1.06 \pm 0.22\end{array}$ \\
\hline Ghaemian et al. [22], 2018 & PCI or CA & $66 / 66$ & $\begin{array}{l}\text { R: } 51 / 15 \\
\text { C: } 42 / 24\end{array}$ & $\begin{array}{l}R: 66.15 \pm 8.63 \\
\text { C: } 65.27 \pm 8.9\end{array}$ & $\begin{array}{l}\text { R: } 41.86 \pm 8.16 \\
\text { C: } 42.77 \pm 9.46\end{array}$ & $\begin{array}{l}\mathrm{R}: 1.5(1.4-1.73) \\
\mathrm{C}: 1.5(1.4-1.6)\end{array}$ \\
\hline Moretti et al. [27], 2018 & PCI & $107 / 116$ & $\begin{array}{l}\text { R: } 74 / 33 \\
\text { C: } 80 / 36\end{array}$ & $\begin{array}{l}\text { R: } 71.8 \pm 10.6 \\
C: 72.6 \pm 9.6\end{array}$ & - & - \\
\hline Valappil et al. [29], 2018 & PCI & $50 / 50$ & $\begin{array}{l}\text { R: } 43 / 7 \\
\mathrm{C}: 40 / 10\end{array}$ & $\begin{array}{l}\mathrm{R}: 62.8 \pm 9.1 \\
\mathrm{C}: 60.5 \pm 8.5\end{array}$ & $\begin{array}{l}\text { R: } 44.3(39.7-49.7) \\
\text { C: } 46.3(40.2-53.1)\end{array}$ & $\begin{array}{l}\mathrm{R}: 1.5(1.3-1.7) \\
\mathrm{C}: 1.4(1.4-1.6)\end{array}$ \\
\hline Gholoobi et al. [23], 2015 & $\mathrm{CA}$ & $25 / 26$ & $\begin{array}{l}\text { R: } 18 / 7 \\
\mathrm{C}: 12 / 14\end{array}$ & $\begin{array}{l}R: 67.08 \pm 12.49 \\
\text { C: } 70.31 \pm 11.18\end{array}$ & - & - \\
\hline Wojciechowska et al. [30], 2018 & PCI & $62 / 61$ & $\begin{array}{l}\text { R: } 42 / 20 \\
\text { C: } 42 / 19\end{array}$ & $\begin{array}{l}R: 64.4 \pm 10.5 \\
C: 62.9 \pm 8.60\end{array}$ & $\begin{array}{l}\text { R: } 105.6 \pm 36.3 \\
\text { C: } 107.3 \pm 36.5\end{array}$ & $\begin{array}{l}R: 0.86 \pm 0.27 \\
C: 0.86 \pm 0.26\end{array}$ \\
\hline Roubille et al. [35], 2019 & PCI or CA & $98 / 104$ & $\begin{array}{l}\text { R: } 68 / 30 \\
\text { C: } 72 / 32\end{array}$ & $\begin{array}{l}\text { R: } 75.6 \pm 9.2 \\
\text { C: } 76.7 \pm 7.6\end{array}$ & $\begin{array}{l}\text { R: } 43 \pm 11 \\
\text { C: } 42 \pm 10\end{array}$ & $\begin{array}{l}\text { R: } 1.69 \pm 0.57 \\
\text { C: } 1.66 \pm 0.50\end{array}$ \\
\hline
\end{tabular}

\section{Results}

\section{Study Selection}

Initially, 956 relevant articles were identified. Based on the inclusion and exclusion criteria, 869 trials were eliminated because they were duplicates, reviews, and basic research or retrospective studies. After scanning the full text of the remaining 87 studies, 16 studies were deemed to be eligible trials $[15,18,22-35]$. The study selection process is outlined in Figure 1.

\section{Study Characteristic and Evaluation of Study Quality}

Table 1 shows the characteristics of the included studies. In total, 2,048 patients were identified, among whom 1,405 were male and 643 were female. There were 1,017 and 1,031 patients in the treatment and control groups, respectively. The risks of bias of the included studies are shown in Figure 2. Three studies had a low risk of bias, 6 had a high and 7 were considered to have an unclear bias. 


\section{Kidney \\ Blood Pressure \\ Research}

Kidney Blood Press Res 2020;45:549-564

Table 1 (continued)

\begin{tabular}{|c|c|c|c|c|}
\hline Study & $\begin{array}{l}\text { Contrast } \\
\text { dose, } \mathrm{mL}\end{array}$ & RIPC time & RIPC application & Definition of CIN \\
\hline $\begin{array}{l}\text { Hoole } \\
\text { et al. [24], } 2009\end{array}$ & $\begin{array}{l}\mathrm{R}: 196.7 \pm 80.1 \\
\mathrm{C}: 187.5 \pm 74.2\end{array}$ & $\begin{array}{l}<1 \text { h before } \\
\text { the PCI }\end{array}$ & $\begin{array}{l}\text { 5-min inflations of a blood pressure cuff to } 200 \mathrm{~mm} \mathrm{Hg} \\
\text { around the upper arm, followed by 5-min intervals of } \\
\text { deflations, repeated } 3 \text { times }\end{array}$ & $\begin{array}{l}\text { An increase in } \mathrm{Scr}>25 \% \text { from the } \\
\text { baseline at } 24 \mathrm{~h} \text { after PCI }\end{array}$ \\
\hline $\begin{array}{l}\text { Balbir Singh } \\
\text { et al. [15], } 2016\end{array}$ & $\begin{array}{l}\text { R: } 197.5 \pm 114.3 \\
\text { C: } 196.3 \pm 118.8\end{array}$ & $\begin{array}{l}<0.5 \mathrm{~h} \text { before } \\
\text { the PCI }\end{array}$ & $\begin{array}{l}\text { 5-min inflations of a blood pressure cuff to } 200 \mathrm{~mm} \mathrm{Hg} \\
\text { around the upper arm, followed by 5-min intervals of } \\
\text { deflations, repeated } 3 \text { times }\end{array}$ & $\begin{array}{l}\text { An increase in } \mathrm{Scr} \geq 25 \% \text { and/or an } \mathrm{Scr} \\
\text { rise } \geq 0.5 \mathrm{mg} / \mathrm{dL} \text { from the baseline within } \\
48 \mathrm{~h} \text { after PCI }\end{array}$ \\
\hline $\begin{array}{l}\text { Xu et al. } \\
{[31], 2014}\end{array}$ & $\begin{array}{l}\text { R: } 171.8 \pm 37.9 \\
\text { C: } 163.3 \pm 39.0\end{array}$ & $\begin{array}{l}<2 \mathrm{~h} \text { before } \\
\text { the PCI }\end{array}$ & $\begin{array}{l}\text { 5-min inflations of a blood pressure cuff to } 200 \mathrm{~mm} \mathrm{Hg} \\
\text { around the upper arm, followed by 5-min intervals of } \\
\text { deflations, repeated } 3 \text { times }\end{array}$ & $\begin{array}{l}\text { An increase in } \mathrm{Scr} \geq 25 \% \text { and/or an } \mathrm{Scr} \\
\text { rise } \geq 0.5 \mathrm{mg} / \mathrm{dL} \text { from the baseline at } 16 \mathrm{~h} \\
\text { after PCI }\end{array}$ \\
\hline $\begin{array}{l}\text { Luo et al. } \\
{[26], 2013}\end{array}$ & $\begin{array}{l}\mathrm{R}: 154.0 \pm 46.0 \\
\mathrm{C}: 145.0 \pm 41.0\end{array}$ & $\begin{array}{l}<2 \text { h before } \\
\text { the PCI }\end{array}$ & $\begin{array}{l}5 \text {-min inflations of a blood pressure cuff to } 200 \mathrm{~mm} \mathrm{Hg} \\
\text { around the upper arm, followed by 5-min intervals of } \\
\text { deflations, repeated } 3 \text { times }\end{array}$ & $\begin{array}{l}\text { An increase in } \mathrm{Scr} \geq 25 \% \text { and/or an } \mathrm{Scr} \\
\text { rise } \geq 0.5 \mathrm{mg} / \mathrm{dL} \text { from the baseline at } 16 \mathrm{~h} \\
\text { after PCI }\end{array}$ \\
\hline $\begin{array}{l}\text { Er et al. } \\
{[18], 2012}\end{array}$ & $\begin{array}{l}\mathrm{R}: 124.0 \pm 44.0 \\
\mathrm{C}: 103.0 \pm 41.0\end{array}$ & $\begin{array}{l}<45 \mathrm{~min} \text { before } \\
\text { the CA }\end{array}$ & $\begin{array}{l}5 \text {-min inflations of a blood pressure cuff to } 200 \mathrm{~mm} \mathrm{Hg} \\
\text { around the upper arm, followed by 5-min intervals of } \\
\text { deflations, repeated } 4 \text { times }\end{array}$ & $\begin{array}{l}\text { An increase in } \mathrm{Scr} \geq 25 \% \text { and/or an Scr } \\
\text { rise } \geq 0.5 \mathrm{mg} / \mathrm{dL} \text { from the baseline at } 48 \mathrm{~h} \\
\text { after CA }\end{array}$ \\
\hline $\begin{array}{l}\text { Igarashi } \\
\text { et al. [25], } 2013\end{array}$ & $\begin{array}{l}\mathrm{R}: 92.9 \pm 33.2 \\
\mathrm{C}: 91.8 \pm 39.4\end{array}$ & $\begin{array}{l}<2 \mathrm{~h} \text { before } \\
\text { the PCI or CA }\end{array}$ & $\begin{array}{l}5 \text {-min inflations of a blood pressure cuff to } 200 \mathrm{~mm} \mathrm{Hg} \\
\text { around the upper arm, followed by 5-min intervals of } \\
\text { deflations, repeated } 4 \text { times }\end{array}$ & $\begin{array}{l}\text { An increase in } \mathrm{Scr} \geq 25 \% \text { and/or an Scr } \\
\text { rise } \geq 0.5 \mathrm{mg} / \mathrm{dL} \text { from the baseline within } \\
48 \mathrm{~h} \text { after PCI or CA }\end{array}$ \\
\hline $\begin{array}{l}\text { Savaj et al. } \\
{[28], 2014}\end{array}$ & $\begin{array}{l}\text { R: } 126.6 \pm 77.2 \\
\text { C: } 123.8 \pm 66.6\end{array}$ & $\begin{array}{l}<15 \text { min before } \\
\text { the } \mathrm{CA}\end{array}$ & $\begin{array}{l}\text { 5-min inflations of a blood pressure cuff to } 200 \mathrm{~mm} \mathrm{Hg} \\
\text { around the upper arm, followed by 5-min intervals of } \\
\text { deflations, repeated } 3 \text { times }\end{array}$ & $\begin{array}{l}\text { An increase in Scr } \geq 30 \% \text { and/or an Scr } \\
\text { rise } \geq 0.3 \mathrm{mg} / \mathrm{dL} \text { from the baseline at } 24 \mathrm{~h} \\
\text { after CA }\end{array}$ \\
\hline $\begin{array}{l}\text { Yamanaka } \\
\text { et al. [32], } 2015\end{array}$ & $\begin{array}{l}\text { R: } 177.0 \pm 53.0 \\
\text { C: } 199.0 \pm 87.0\end{array}$ & - & $\begin{array}{l}\text { 5-min inflations of a blood pressure cuff to } 200 \mathrm{~mm} \mathrm{Hg} \\
\text { around the upper arm, followed by 5-min intervals of } \\
\text { deflations, repeated } 3 \text { times }\end{array}$ & $\begin{array}{l}\text { An increase in } \mathrm{Scr} \geq 25 \% \text { and/or an } \mathrm{Scr} \\
\text { rise } \geq 0.5 \mathrm{mg} / \mathrm{dL} \text { from the baseline within } \\
48-72 \mathrm{~h} \text { after PCI }\end{array}$ \\
\hline $\begin{array}{l}\text { Zagidullin } \\
\text { et al. [33], } 2017\end{array}$ & $\begin{array}{l}R: 155.8 \pm 16.9 \\
\text { C: } 148.3 \pm 16.7\end{array}$ & $\begin{array}{l}<1 \mathrm{~h} \text { before } \\
\text { the CA }\end{array}$ & $\begin{array}{l}\text { 5-min inflations of a blood pressure cuff to level } 50 \mathrm{~mm} \mathrm{Hg} \\
\text { above SBP around the upper arm, followed by } 5 \text {-min } \\
\text { intervals of deflations, repeated } 3 \text { times }\end{array}$ & $\begin{array}{l}\text { An increase in } \mathrm{Scr} \geq 25 \% \text { and } / \text { or an } \mathrm{Scr} \\
\text { rise } \geq 0.5 \mathrm{mg} / \mathrm{dL} \text { from the baseline at } 48 \mathrm{~h} \\
\text { after CA }\end{array}$ \\
\hline $\begin{array}{l}\text { Zhou et al. } \\
{[34], 2018}\end{array}$ & $\begin{array}{l}\mathrm{R}: 114.76 \pm 44.22 \\
\mathrm{C}: 108.82 \pm 43.25\end{array}$ & $\begin{array}{l}<1 \text { h before } \\
\text { the PCI }\end{array}$ & $\begin{array}{l}5 \text {-min inflations of a blood pressure cuff to } 200 \mathrm{~mm} \mathrm{Hg} \\
\text { around the upper arm, followed by 5-min intervals of } \\
\text { deflations, repeated } 4 \text { times }\end{array}$ & $\begin{array}{l}\text { An increase in } \mathrm{Scr} \geq 25 \% \text { and/or an } \mathrm{Scr} \\
\text { rise } \geq 0.5 \mathrm{mg} / \mathrm{dL} \text { from the baseline within } \\
48-72 \mathrm{~h} \text { after PCI }\end{array}$ \\
\hline $\begin{array}{l}\text { Ghaemian } \\
\text { et al. [22], } 2018\end{array}$ & $\begin{array}{l}\text { R: } 90(80-112.5) \\
\text { C: } 100(80-116)\end{array}$ & $\begin{array}{l}<40 \text { min before } \\
\text { PCI or CA }\end{array}$ & $\begin{array}{l}\text { 5-min inflations of a blood pressure cuff to level } 50 \mathrm{~mm} \mathrm{Hg} \\
\text { above SBP around the upper arm, followed by } 5 \text {-min } \\
\text { intervals of deflations, repeated } 4 \text { times }\end{array}$ & $\begin{array}{l}\text { An Scr rise } \geq 0.3 \mathrm{mg} / \mathrm{dL} \text { from the baseline } \\
\text { within } 48-72 \mathrm{~h} \text { after PCI or cCA }\end{array}$ \\
\hline $\begin{array}{l}\text { Moretti et al. } \\
{[27], 2018}\end{array}$ & $\begin{array}{l}\text { R: } 171.4 \pm 78.6 \\
\text { C: } 174.4 \pm 83.7\end{array}$ & $\begin{array}{l}<45 \text { min before } \\
\text { the PCI }\end{array}$ & $\begin{array}{l}\text { 5-min inflations of a blood pressure cuff to } 200 \mathrm{~mm} \mathrm{Hg} \\
\text { around the upper arm, followed by 5-min intervals of } \\
\text { deflations, repeated } 4 \text { times }\end{array}$ & $\begin{array}{l}\text { An increase in } \mathrm{Scr} \geq 25 \% \text { and/or an Scr } \\
\text { rise } \geq 0.5 \mathrm{mg} / \mathrm{dL} \text { from the baseline within } \\
48 \mathrm{~h} \text { after PCI }\end{array}$ \\
\hline $\begin{array}{l}\text { Valappil et al. } \\
\text { [29], } 2018\end{array}$ & - & $\begin{array}{l}<45 \text { min before } \\
\text { the PCI }\end{array}$ & $\begin{array}{l}\text { 5-min inflations of a blood pressure cuff to level } 50 \mathrm{~mm} \mathrm{Hg} \\
\text { above SBP around the upper arm, followed by } 5 \text {-min } \\
\text { intervals of deflations, repeated } 4 \text { times }\end{array}$ & $\begin{array}{l}\text { An increase in Scr } \geq 25 \% \text { and/or an Scr } \\
\text { rise } \geq 0.5 \mathrm{mg} / \mathrm{dL} \text { from the baseline within } \\
24-48 \mathrm{~h} \text { after PCI }\end{array}$ \\
\hline $\begin{array}{l}\text { Gholoobi } \\
\text { et al. [23], } 2015\end{array}$ & - & $\begin{array}{l}<1 \mathrm{~h} \text { before } \\
\text { the CA }\end{array}$ & $\begin{array}{l}\text { 5-min inflations of a blood pressure cuff to level } 50 \mathrm{~mm} \mathrm{Hg} \\
\text { above SBP around the upper arm, followed by } 5 \text {-min } \\
\text { intervals of deflations, repeated } 4 \text { times }\end{array}$ & $\begin{array}{l}\text { An Scr rise } \geq 0.3 \mathrm{mg} / \mathrm{dL} \text { from the baseline } \\
\text { within } 48 \mathrm{~h} \text { after } \mathrm{CA}\end{array}$ \\
\hline $\begin{array}{l}\text { Wojciechowska } \\
\text { et al. [30], } 2018\end{array}$ & $\begin{array}{l}R: 155.5 \pm 76.7 \\
\text { C: } 143.7 \pm 55.7\end{array}$ & $\begin{array}{l}<2 \mathrm{~h} \text { before } \\
\text { the PCI }\end{array}$ & $\begin{array}{l}\text { 5-min inflations of a blood pressure cuff to } 200 \mathrm{~mm} \mathrm{Hg} \\
\text { around the upper arm, followed by 5-min intervals of } \\
\text { deflations, repeated } 3 \text { times }\end{array}$ & $\begin{array}{l}\text { An increase in } \mathrm{Scr} \geq 25 \% \text { and/or an } \mathrm{Scr} \\
\text { rise } \geq 0.5 \mathrm{mg} / \mathrm{dL} \text { from the baseline within } \\
24-72 \mathrm{~h} \text { after contrast administration }\end{array}$ \\
\hline $\begin{array}{l}\text { Roubille et al. } \\
\text { [35], } 2019\end{array}$ & $\begin{array}{l}\text { C: } 73(45-121) \\
\text { R: } 80(50-111)\end{array}$ & - & $\begin{array}{l}5 \text {-min inflations of a blood pressure cuff to } 200 \mathrm{~mm} \mathrm{Hg} \\
\text { around the upper arm, followed by 5-min intervals of } \\
\text { deflations, repeated } 4 \text { times }\end{array}$ & $\begin{array}{l}\text { An increase in } \mathrm{Scr} \geq 25 \% \text { and/or an } \mathrm{Scr} \\
\text { rise } \geq 0.5 \mathrm{mg} / \mathrm{dL} \text { from the baseline within } \\
48-72 \mathrm{~h} \text { after PCI }\end{array}$ \\
\hline
\end{tabular}

Data are presented as means \pm SD or medians (quartiles Q1-Q3). R, RIPC group; C, control group; CIN, contrast-induced nephropathy; PCI, percutaneous coronary intervention; CA, coronary angiography; eGFR, estimated glomerular filtration rate; Scr, serum creatinine; RIPC, remote ischemic preconditioning; SBP, systolic blood pressure; -, not mentioned. 


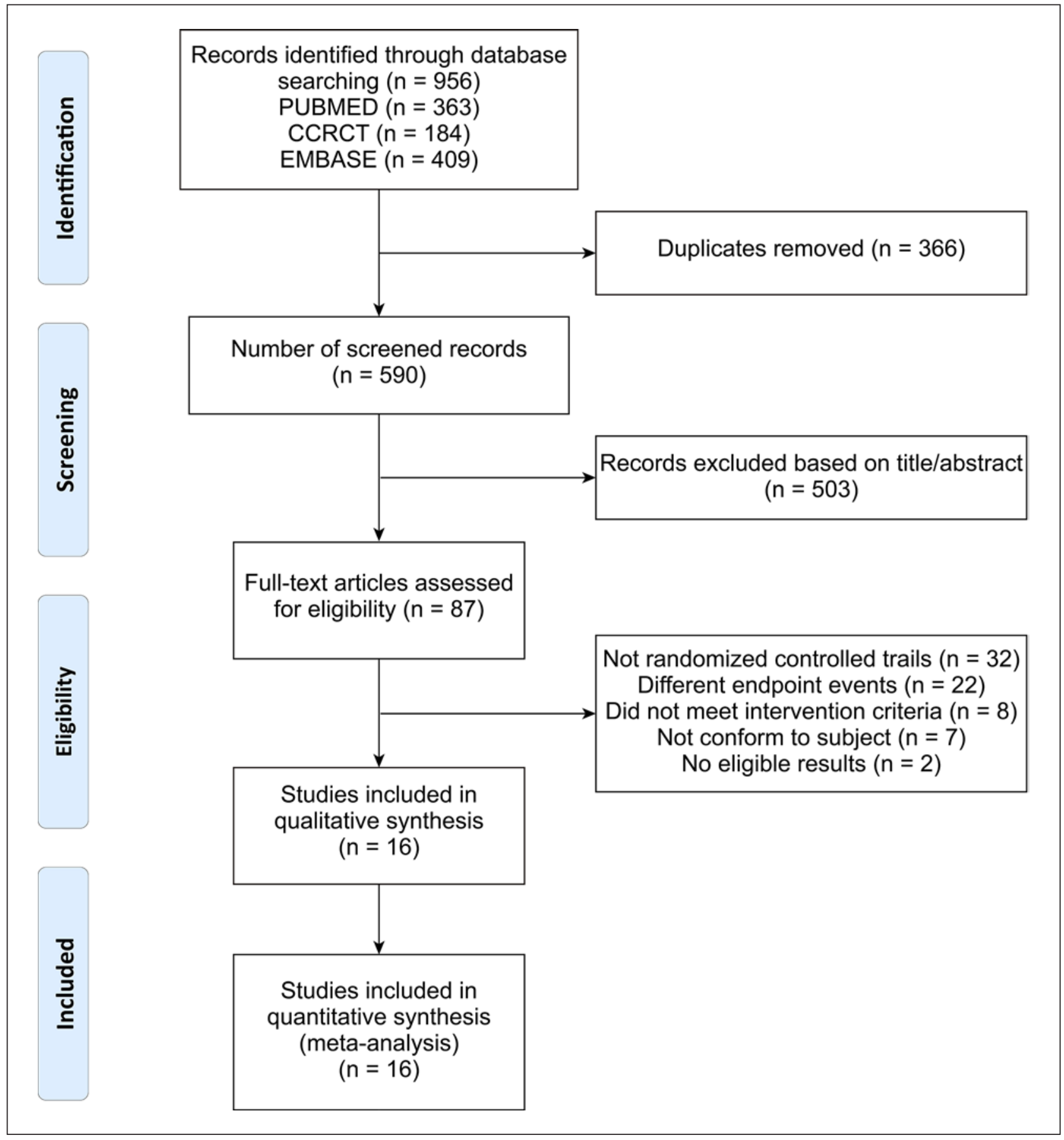

Fig. 1. Flow diagram of study selection. CCRCT, Cochrane Central Register of Controlled Trials.

Effect of RIPC on the Incidence of CIN

All the 16 RCTs reported the number of patients suffering from CIN in the RIPC and control groups. The analysis of outcomes demonstrated that RIPC reduced the incidence of CIN compared to the control group (RR $0.50,95 \%$ CI $0.39-0.65 ; p<0.001$ ). Subgroup analyses showed that RIPC decreased the incidence of CIN in patients with eGRF $<60 \mathrm{~mL} / \mathrm{min} / 1.73 \mathrm{~m}^{2}$ (RR $0.53,95 \%$ CI $0.38-0.75 ; p<0.001$ ), but not in patients with eGRF $\geq 60 \mathrm{~mL} / \mathrm{min} / 1.73 \mathrm{~m}^{2}$ 


\section{Kidney \\ Blood Pressure \\ Research}

Fig. 2. Risk of bias graph: review of authors' judgments about each risk of bias item presented as percentages across all included studies.

Table 2. Sensitivity analysis based on the different definitions of contrast-enhanced nephropathy in the included studies

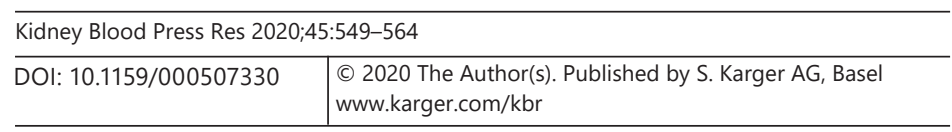

Deng et al.: Remote Ischemic Preconditioning Prevents Contrast-Induced Nephropathy

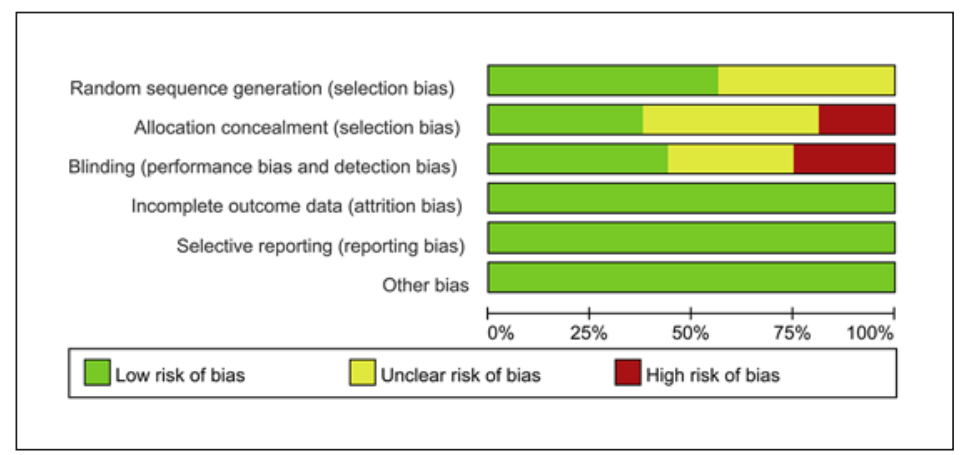

\begin{tabular}{llll}
\hline Study & $\mathrm{RR}$ & $95 \% \mathrm{CI}$ & $p$ value \\
\hline Hoole et al. [24], 2009 & 0.5 & $0.38-0.65$ & $<0.001$ \\
\hline Xu et al. [31], 2014 & 0.49 & $0.37-0.63$ & $<0.001$ \\
\hline Luo et al. [26], 2013 & 0.49 & $0.38-0.64$ & $<0.001$ \\
\hline Savaj et al. [28], 2014 & 0.51 & $0.39-0.66$ & $<0.001$ \\
\hline Valappil et al. [29], 2018 & 0.48 & $0.36-0.64$ & $<0.001$ \\
\hline Gholoobi et al. [23], 2015 & 0.50 & $0.38-0.65$ & $<0.001$ \\
\hline These 6 studies & 0.45 & $0.32-0.62$ & $<0.001$ \\
\hline
\end{tabular}




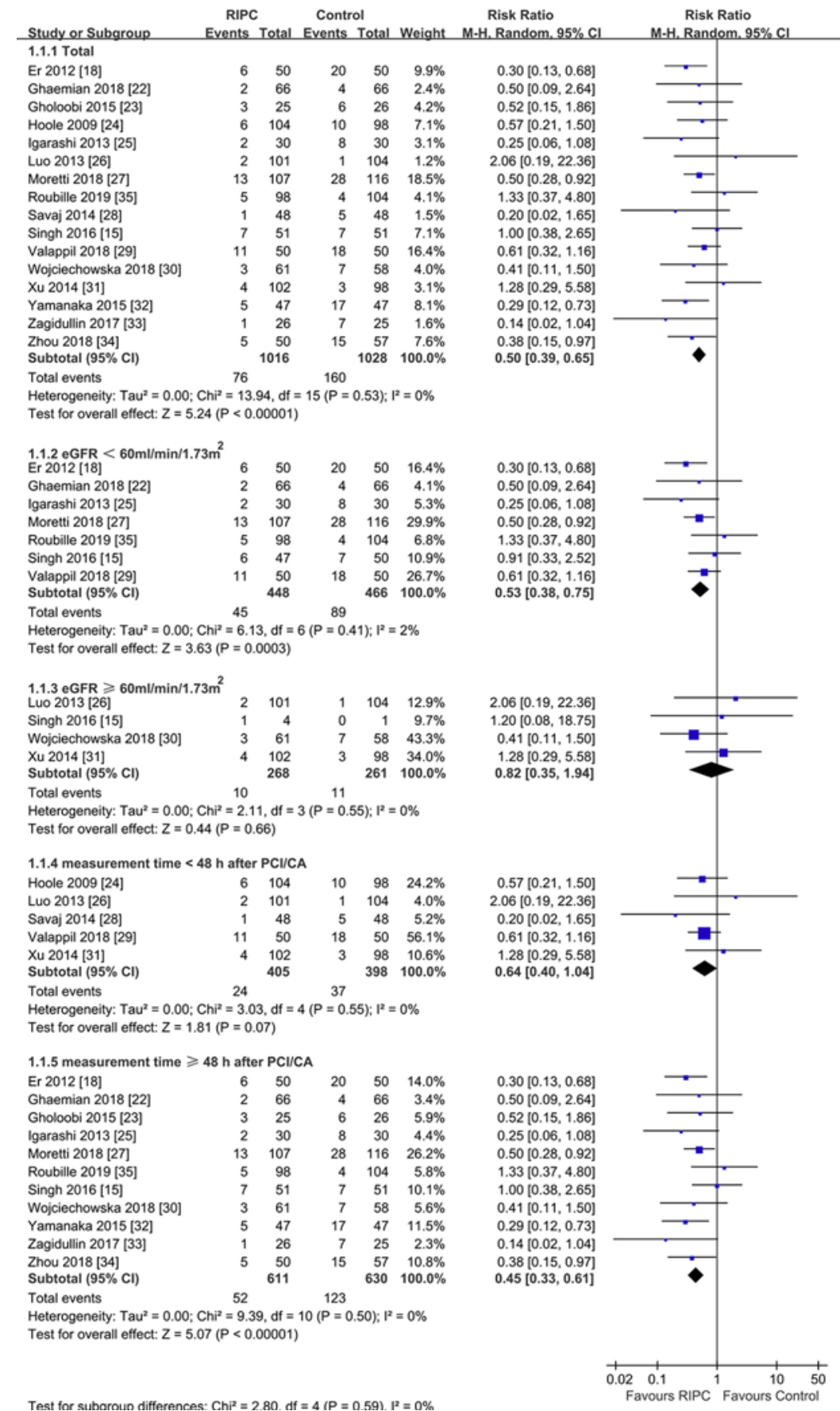

Fig. 3. Effect of RIPC on the incidence of CIN. 


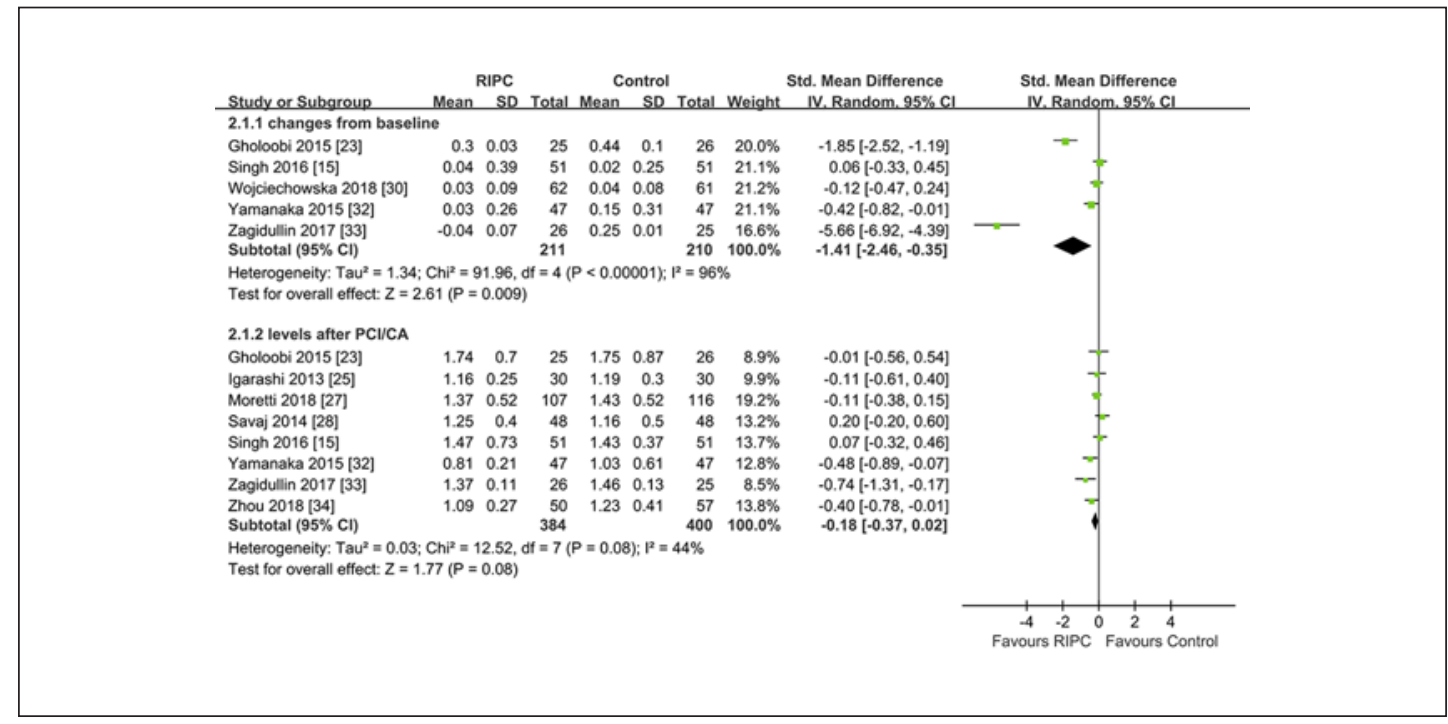

Fig. 4. Effect of RIPC on serum creatinine.

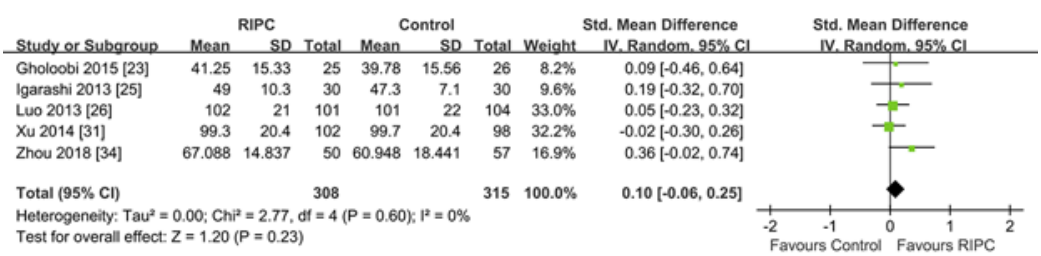

Fig. 5. Effect of RIPC on eGFR.

in the RIPC group compared to the sham group. However, Ghaemian et al. [22] found that there was no statistically significant difference between the RIPC and control groups in serum creatinine levels $48-72 \mathrm{~h}$ after the procedure.

\section{Effect of RIPC on eGFR}

Five studies were included in the meta-analysis, and the result showed that there was no difference between RIPC and control groups in eGFR after PCI/CA (SMD 0.10, 95\% CI -0.06 to $0.25 ; p=0.23$; Fig. 5). In addition, 3 studies reported serum creatinine in the form of medians with 25 th and 75 th quartiles. Two studies reported no statistically significant difference between the RIPC and control groups in eGFR after the procedure [24, 35]. In contrast, Valappil et al. [29] found significant improvement in eGFR after the procedure in the RIPC group compared to the sham one at 24 h, 48 h, 2 weeks, and 6 weeks. Moreover, one study compared the maximum decrease in eGFR between the RIPC group and the control group [32]. In this study, the maximum decrease from baseline in eGFR was higher in the control group than in the RIPC group $(p=0.003)$.

\section{Effect of RIPC on NGAL}

Four studies reported the levels of NGAL after PCI/CA, and 3 of them were included in the meta-analysis. The results showed that the level of NGAL after PCI/CA in the RIPC group 


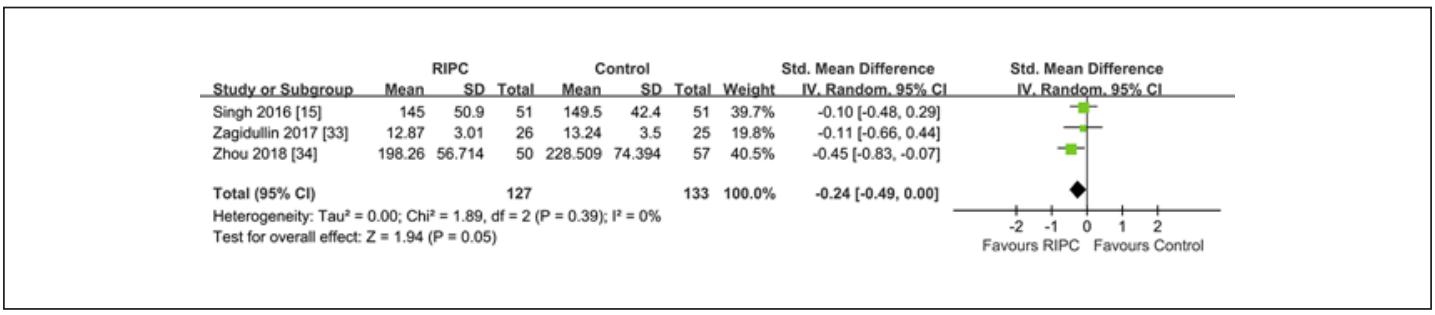

Fig. 6. Effect of RIPC on NGAL.

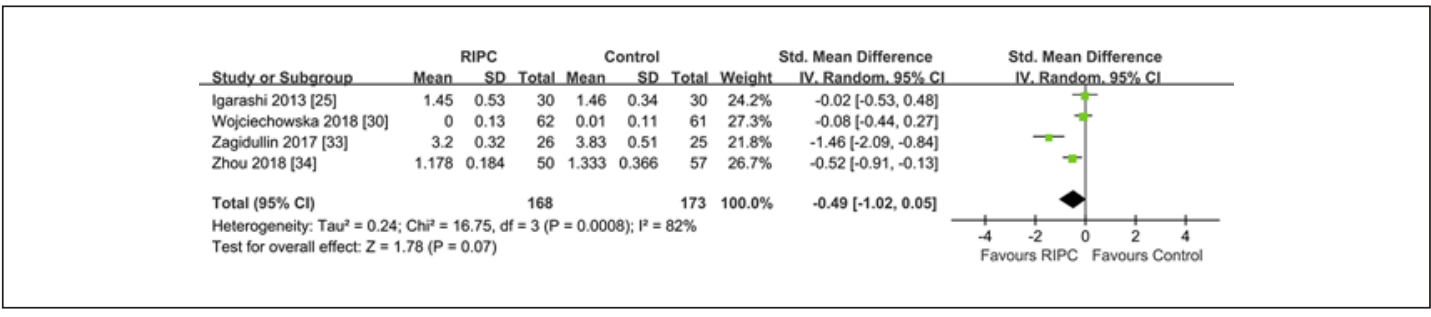

Fig. 7. Effect of RIPC on cystatin C.

was lower compared to that of controls (SMD $-0.24,95 \%$ CI -0.49 to $0.00 ; p=0.05$, Fig. 6). In the study by Er et al. [18], urinary NGAL increased $6 \mathrm{~h}$ after contrast medium use by $244.48 \%$ in the control group and $178.28 \%$ in the RIPC group $(p<0.001)$. This difference remained after $24 \mathrm{~h}(p<0.001)$ and $48 \mathrm{~h}(p<0.001)$. In addition, 2 articles reported the changes of NGAL in their RIPC and sham groups. Zagidullin et al. [33] found that the NGAL level was lower from baseline in the RIPC group while it was higher from baseline in the sham group after $48 \mathrm{~h}(p=0.002)$. This is inconsistent with Balbir Singh et al. [15] where no significant differences in the changes of NGAL levels were found between RIPC and control groups.

\section{Effect of RIPC on Cystatin C}

Five studies reported the levels of serum cystatin $\mathrm{C}$ after PCI/CA and 4 of them were included in the meta-analysis. According to the result shown in Figure 7, we observed that the level of cystatin $C$ after the procedure in the RIPC group was lower compared to that of control, although the difference was not statistically significant (SMD $-0.49,95 \%$ CI -1.02 to $0.05 ; p=$ 0.07). Er et al. [18] reported that serum cystatin C increment 24 and $48 \mathrm{~h}$ after CA reflected major renal injury in the control group compared with patients with RIPC $(24 \mathrm{~h}: p<0.001$; $48 \mathrm{~h}: p<0.001$ ). In addition, 3 RCTs reported changes in serum cystatin $\mathrm{C}$ in the sham and RIPC groups. Zagidullin et al. [33] suggested that the cystatin C level was lower from baseline in the RIPC group while it was higher from baseline in the sham group after $48 \mathrm{~h}(p=0.018)$. However, 2 studies found no statistically significant difference between the 2 groups in serum cystatin $\mathrm{C}$ changes after the procedure $[22,30]$.

\section{Effect of RIPC on Clinical Adverse Events}

Five articles reported the need for hemodialysis and rehospitalization, while 6 articles reported the outcomes of mortality. The result showed that there was no difference between the RIPC and control groups in mortality (RR 0.69, 95\% CI $0.34-1.40 ; p=0.31$ ) and the requirement of hemodialysis (RR $0.87,95 \% \mathrm{CI} 0.27-2.84 ; p=0.82$ ) and rehospitalization (RR 0.75 , 95\% CI 0.49-1.16; $p=0.19$; Fig. 8). 


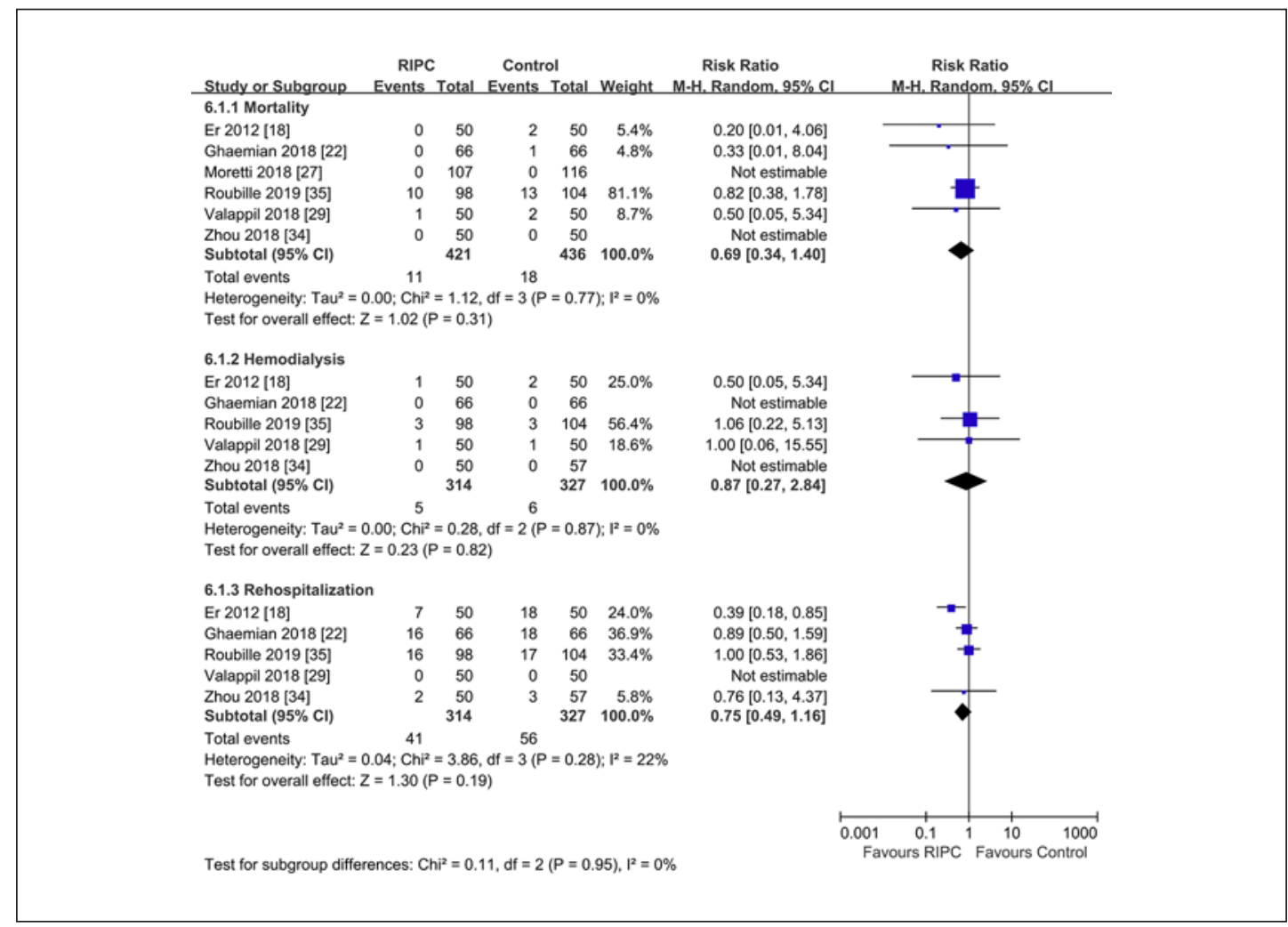

Fig. 8. Effect of RIPC on clinical adverse events.

\section{Publication Bias}

Publication bias was not tested for outcomes except for the incidence of CIN because of the small number of studies (Fig. 9). Funnel plots for the 16 trials exhibited symmetric patterns, suggesting that there was no obvious publication bias for this outcome.

\section{Discussion}

The main findings of this meta-analysis can be summarized as follows. First, RIPC reduced the incidence of CIN in patients undergoing PCI/CA. Furthermore, subgroup analyses showed that RIPC decreased the incidence of CIN in patients with eGRF $<60 \mathrm{~mL} / \mathrm{min} / 1.73 \mathrm{~m}^{2}$ but not in patients with eGRF $\geq 60 \mathrm{~mL} / \mathrm{min} / 1.73 \mathrm{~m}^{2}$ at baseline, and the incidence of CIN was lower in the RIPC group compared with the control group in the subgroup of measurement time $\geq 48 \mathrm{~h}$ after PCI/CA, but not in the subgroup of measurement time $<48 \mathrm{~h}$. Second, the increase in serum creatinine after the procedure was significantly lower in patients with RIPC compared to control patients. And the levels of NGAL and cystatin C after the procedure in the RIPC group were lower compared to that of controls, although the difference was not statistically significant in cystatin C. Third, RIPC did not have any remarkable effect on eGFR and mortality, and the requirement of hemodialysis and rehospitalization.

Although the pathogenesis of CIN is not completely understood, there is increasing evidence that CIN is the result of renal hypoxia injury and the direct cytotoxicity of contrast agents to the kidney [36]. Renal ischemia and reperfusion injury play an important role in the occurrence of CIN [37, 38]. Furthermore, the formation of free radicals, reactive oxygen 


\section{Kidney \\ Blood Pressure \\ Research}

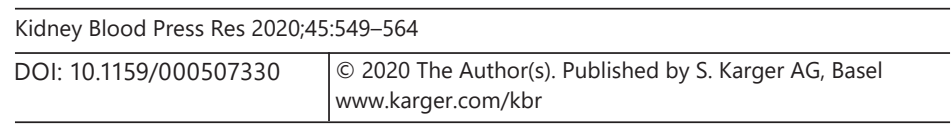

Deng et al.: Remote Ischemic Preconditioning Prevents Contrast-Induced Nephropathy
Fig. 9. Funnel plot of the incidence of CIN.

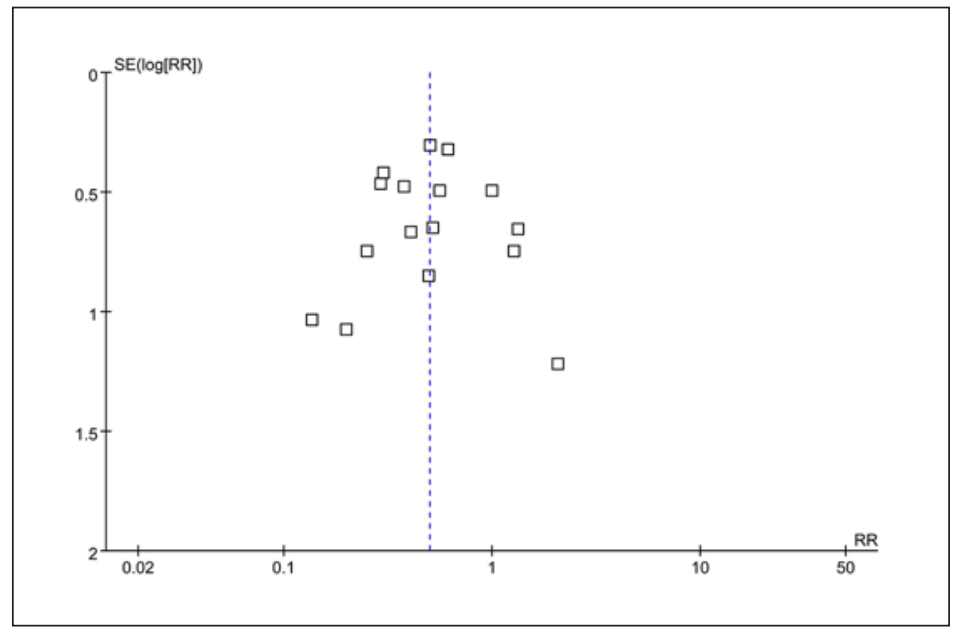

species, and inflammatory factors could lead to direct cytotoxicity and renal tubular epithelial apoptosis [39]. Being a novel nonpharmacological approach, RIPC might attenuate the organ damage caused by prolonged ischemia-reperfusion by providing repeated, transient, and mild ischemia-reperfusion in advance. It has been acknowledged that RIPC confers cardioprotection during the ischemia-reperfusion process [40,41], but at present, its protective effects on renal function are controversial. The results of this study indicate that RIPC can decrease the incidence of CIN in patients undergoing PCI/CA. Furthermore, subgroup analyses showed that RIPC decreased the incidence of CIN in patients with $\mathrm{eGRF}<60 \mathrm{~mL} / \mathrm{min} / 1.73 \mathrm{~m}^{2}$ but not in patients with $\mathrm{eGRF} \geq 60 \mathrm{~mL} / \mathrm{min} / 1.73 \mathrm{~m}^{2}$. It is suggested that patients with moderate renal impairment most likely could benefit from RIPC. And the incidence of CIN was lower in the RIPC group compared with the control group in the subgroup of measurement time $\geq 48 \mathrm{~h}$ after PCI/CA but not in the subgroup of measurement time $<48 \mathrm{~h}$. It is suggested that the protective effect of RIPC on CIN might be more pronounced over $48 \mathrm{~h}$ after PCI/CA. At present, the mechanism of the protective effect of RIPC is still unclear. Some studies have suggested that the mechanism of renal protection by RIPC is that it can play a role in antiinflammatory, antioxidant, and nerve and humoral pathways by activating a variety of factors [42-44]. Recently studies suggested that RIPC could reduce renal damage in CIN through the activation of the tumor necrosis factor- $\alpha /$ neural factor- $\kappa B$ pathway and then increases the expression of renal enzymes and plays the role of anti-inflammatory, antiapoptosis, and antioxidant protection of the kidney [45].

Cystatin C can freely pass through the glomerular filtration and be fully reabsorbed by renal tubular epithelial cells without returning to the blood. Furthermore, renal tubules do not secrete cystatin C. Therefore, it is not affected by factors such as gender, diet, and body weight. Thus, cystatin $\mathrm{C}$ has a higher sensitivity and specificity of the predictive power in the identification of AKI compared to serum creatinine and blood urea nitrogen [46, 47]. In this meta-analysis, we found that the level of cystatin $\mathrm{C}$ after the procedure in the RIPC group was lower compared to that of controls, although the difference was not statistically significant. NGAL is a protein released from kidney tubular cells after harmful stimuli. It has been shown that NGAL appears earlier and is more sensitive than creatinine and urea for the diagnosis of AKI $[48,49]$. In this meta-analysis, we found that the level of NGAL after the procedure in the RIPC group was lower compared to that of controls, suggesting that RIPC may alleviate renal damage in patients undergoing $\mathrm{PCI} / \mathrm{CA}$.

Based on the results of the present meta-analysis, RIPC failed to show a significant effect on eGFR, mortality, and requirement of hemodialysis and rehospitalization. The potential 
reasons for our negative results about the above outcomes concerned the few studies included in these analyses and the absence of subgroup analyses. Thus, large-scale RCTs are needed to confirm the potential effect of RIPC on eGFR, mortality, and requirement of hemodialysis and rehospitalization during PCI/CA.

So far, 2 meta-analyses have been performed to determine the effect of RIPC on CIN [50, 51]. However, Hu et al. [51] included 10 RCTs with 1,167 patients, and Bei et al. [50] included 7 RCTs with 957 patients, whereas the present study included 16 RCTs with 2,048 patients. Inconsistent with the results of these 2 meta-analyses, 3 recent trials reported that RIPC did not significantly reduce CIN $[29,30,35]$. Here, we included 6 updated additional RCTs to assess the effect of RIPC for CIN in a more comprehensive manner. Since eGFR $<60 \mathrm{~mL} /$ $\min / 1.73 \mathrm{~m}^{2}$ is a risk factor for CIN, we conducted a subgroup analysis based on baseline eGRF. However, Bei et al. [50] performed the subgroup analysis according to whether the mean eGFR was $\geq 60 \mathrm{~mL} / \mathrm{min} / 1.73 \mathrm{~m}^{2}$, which would introduce some biases in meta-analysis and tend to confuse the result. In addition, because the measurement time varied across the included RCTs, we conducted a subgroup analysis based on measurement time $<48$ or $\geq 48 \mathrm{~h}$ after PCI/CA. Furthermore, given that the definition of CIN varied in the included studies, we performed a sensitivity analysis to confirm the effects of different definitions of CIN on the result. Sensitivity analysis revealed that different definitions of CIN had little effect on the result. Finally, the present study explored the effects of RIPC on NGAL and cystatin C, which are crucial for the early diagnosis of kidney injury.

Despite the above strengths, there are some limitations. First, there was heterogeneity in eGFR and serum creatinine across the included RCTs as well as heterogeneity in the definition of CIN, which may weaken the results of this meta-analysis. Second, only a few studies were included in analyses for NGAL, cystatin C, eGFR, mortality, and requirement of hemodialysis and rehospitalization. Third, subgroup analysis was performed only for CIN because of inadequate data. Fourth, only 3 articles involved in this study had a low risk of bias and 6 had a high risk. Thus, further large-scale RCTs are needed to confirm these findings.

\section{Conclusion}

The application of RIPC to patients with moderate renal impairment undergoing PCI/CA may be an effective method to reduce the risk of the occurrence of CIN. However, this needs to be confirmed by further high-quality evidence.

\section{Statement of Ethics}

The Preferred Reporting Items for Systematic Reviews and Meta-Analyses (PRISMA) guidelines were followed in this study.

\section{Conflict of Interest Statement}

All the authors declared no competing interests. 


\section{Funding Sources}

This study was supported by the Natural Science Foundation of Hunan Province (2018JJ3474) and the Scientific Research Subject of Health and Family Planning Commission of Hunan Province (20180227).

\section{Author Contributions}

J.D., J.O., and H.X. designed the study. Y.L. and J.D. were responsible for acquisition and analysis of data. X.W. and X.S. were responsible for data interpretation. Y.L. and J.D. wrote the manuscript. All authors critically revised the paper and approved the final version.

\section{References}

1 Langabeer JR 2nd, Henry TD, Kereiakes DJ, Dellifraine J, Emert J, Wang Z, et al. Growth in percutaneous coronary intervention capacity relative to population and disease prevalence. J Am Heart Assoc. 2013 Oct; 2(6):e000370.

2 Narula A, Mehran R, Weisz G, Dangas GD, Yu J, Généreux P, et al. Contrast-induced acute kidney injury after primary percutaneous coronary intervention: results from the HORIZONS-AMI substudy. Eur Heart J. 2014 Jun;35(23):1533-40.

3 Almendarez M, Gurm HS, Mariani J Jr, Montorfano M, Brilakis ES, Mehran R, et al. Procedural Strategies to Reduce the Incidence of Contrast-Induced Acute Kidney Injury During Percutaneous Coronary Intervention. JACC Cardiovasc Interv. 2019 Oct;12(19):1877-88.

4 Morcos SK, Thomsen HS, Webb JA. Contrast-media-induced nephrotoxicity: a consensus report. Contrast Media Safety Committee, European Society of Urogenital Radiology (ESUR). Eur Radiol. 1999;9(8):1602-13.

5 Tepel M, Aspelin P, Lameire N. Contrast-induced nephropathy: a clinical and evidence-based approach. Circulation. 2006 Apr;113(14):1799-806.

6 Barrett BJ, Parfrey PS. Clinical practice. Preventing nephropathy induced by contrast medium. N Engl J Med. 2006 Jan;354(4):379-86.

7 McDonald JS, McDonald RJ, Comin J, Williamson EE, Katzberg RW, Murad MH, et al. Frequency of acute kidney injury following intravenous contrast medium administration: a systematic review and meta-analysis. Radiology. 2013 Apr;267(1):119-28.

8 Fan Z, Li Y, Ji H, Jian X. Efficacy of Oral Nicorandil to Prevent Contrast-Induced Nephropathy in Patients with Chronic Renal Dysfunction Undergoing an Elective Coronary Procedure. Kidney Blood Press Res. 2019;44(6): 1372-82.

9 Azzalini L, Candilio L, McCullough PA, Colombo A. Current Risk of Contrast-Induced Acute Kidney Injury After Coronary Angiography and Intervention: A Reappraisal of the Literature. Can J Cardiol. 2017 Oct;33(10): 1225-8.

10 Brueck M, Cengiz H, Hoeltgen R, Wieczorek M, Boedeker RH, Scheibelhut C, et al. Usefulness of N-acetylcysteine or ascorbic acid versus placebo to prevent contrast-induced acute kidney injury in patients undergoing elective cardiac catheterization: a single-center, prospective, randomized, double-blind, placebo-controlled trial. J Invasive Cardiol. 2013 Jun;25(6):276-83.

11 Palli E, Makris D, Papanikolaou J, Garoufalis G, Tsilioni I, Zygoulis P, et al. The impact of N-acetylcysteine and ascorbic acid in contrast-induced nephropathy in critical care patients: an open-label randomized controlled study. Crit Care. 2017 Oct;21(1):269.

12 Berwanger O, Cavalcanti AB, Sousa AM, Buehler A, Castello-Júnior HJ, Cantarelli MJ, et al.; Acetylcysteine for Contrast-Induced Nephropathy Trial Investigators. Acetylcysteine for the prevention of renal outcomes in patients with diabetes mellitus undergoing coronary and peripheral vascular angiography: a substudy of the acetylcysteine for contrast-induced nephropathy trial. Circ Cardiovasc Interv. 2013 Apr;6(2):139-45.

13 Weisbord SD, Gallagher M, Jneid H, Garcia S, Cass A, Thwin SS, et al.; PRESERVE Trial Group. Outcomes after Angiography with Sodium Bicarbonate and Acetylcysteine. N Engl J Med. 2018 Feb;378(7):603-14.

14 Gassanov N, Nia AM, Caglayan E, Er F. Remote ischemic preconditioning and renoprotection: from myth to a novel therapeutic option? J Am Soc Nephrol. 2014 Feb;25(2):216-24.

15 Balbir Singh G, Ann SH, Park J, Chung HC, Lee JS, Kim ES, et al. Remote Ischemic Preconditioning for the Prevention of Contrast-Induced Acute Kidney Injury in Diabetics Receiving Elective Percutaneous Coronary Intervention. PLoS One. 2016 Oct;11(10):e0164256.

16 Przyklenk K, Bauer B, Ovize M, Kloner RA, Whittaker P. Regional ischemic 'preconditioning' protects remote virgin myocardium from subsequent sustained coronary occlusion. Circulation. 1993 Mar;87(3):893-9. 
Deng et al.: Remote Ischemic Preconditioning Prevents Contrast-Induced Nephropathy

17 Tapuria N, Kumar Y, Habib MM, Abu Amara M, Seifalian AM, Davidson BR. Remote ischemic preconditioning: a novel protective method from ischemia reperfusion injury-a review. J Surg Res. 2008 Dec;150(2):304-30.

18 Er F, Nia AM, Dopp H, Hellmich M, Dahlem KM, Caglayan E, et al. Ischemic preconditioning for prevention of contrast medium-induced nephropathy: randomized pilot RenPro Trial (Renal Protection Trial). Circulation. 2012 Jul;126(3):296-303.

19 Zarbock A, Kellum JA. Remote Ischemic Preconditioning and Protection of the Kidney-A Novel Therapeutic Option. Crit Care Med. 2016 Mar;44(3):607-16.

20 Jensen HA, Loukogeorgakis S, Yannopoulos F, Rimpiläinen E, Petzold A, Tuominen H, et al. Remote ischemic preconditioning protects the brain against injury after hypothermic circulatory arrest. Circulation. 2011 Feb; 123(7):714-21.

21 Liberati A, Altman DG, Tetzlaff J, Mulrow C, Gøtzsche PC, Ioannidis JP, et al. The PRISMA statement for reporting systematic reviews and meta-analyses of studies that evaluate healthcare interventions: explanation and elaboration. BMJ. 2009 Jul;339:b2700.

22 Ghaemian A, Yazdani J, Azizi S, Farsavian AA, Nabati M, Malekrah A, et al. Remote ischemic preconditioning to reduce contrast-induced acute kidney injury in chronic kidney disease: a randomized controlled trial. BMC Nephrol. 2018 Dec;19(1):373.

23 Gholoobi A, Sajjadi SM, Shabestari MM, Eshraghi A, Shamloo AS. The Impact of Remote Ischemic Pre-Conditioning on Contrast-Induced Nephropathy in Patients Undergoing Coronary Angiography and Angioplasty: A Double-Blind Randomized Clinical Trial. Electron Physician. 2015 Dec;7(8):1557-65.

24 Hoole SP, Heck PM, Sharples L, Khan SN, Duehmke R, Densem CG, et al. Cardiac Remote Ischemic Preconditioning in Coronary Stenting (CRISP Stent) Study: a prospective, randomized control trial. Circulation. 2009 Feb;119(6):820-7.

25 Igarashi $\mathrm{G}$, Ino $\mathrm{K}$, Watanabe $\mathrm{H}$, Ito $\mathrm{H}$. Remote ischemic pre-conditioning alleviates contrast-induced acute kidney injury in patients with moderate chronic kidney disease. Circ J. 2013;77(12):3037-44.

26 Luo SJ, Zhou YJ, Shi DM, Ge HL, Wang JL, Liu RF. Remote ischemic preconditioning reduces myocardial injury in patients undergoing coronary stent implantation. Can J Cardiol. 2013 Sep;29(9):1084-9.

27 Moretti C, Cerrato E, Cavallero E, Lin S, Rossi ML, Picchi A, et al. The EUROpean and Chinese cardiac and renal Remote Ischemic Preconditioning Study (EURO-CRIPS CardioGroup I): A randomized controlled trial. Int J Cardiol. 2018 Apr;257:1-6.

28 Savaj S, Savoj J, Jebraili I, Sezavar SH. Remote ischemic preconditioning for prevention of contrast-induced acute kidney injury in diabetic patients. Iran J Kidney Dis. 2014 Nov;8(6):457-60.

29 Valappil SP, Kunjukrishnapillai S, Viswanathan S, Koshy AG, Gupta PN, Velayudhan RV, et al. Remote ischemic preconditioning for prevention of contrast induced nephropathy-Insights from an Indian study. Indian Heart J. 2018 Nov - Dec;70(6):857-63.

30 Wojciechowska M, Zarębiński M, Pawluczuk P, Gralak-Łachowska D, Pawłowski L, Loska W, et al. Remote Ischemic Preconditioning in Renal Protection During Elective Percutaneous Coronary Intervention. Adv Exp Med Biol. 2018;1116:19-25.

31 Xu X, Zhou Y, Luo S, Zhang W, Zhao Y, Yu M, et al. Effect of remote ischemic preconditioning in the elderly patients with coronary artery disease with diabetes mellitus undergoing elective drug-eluting stent implantation. Angiology. 2014 Sep;65(8):660-6.

32 Yamanaka T, Kawai Y, Miyoshi T, Mima T, Takagaki K, Tsukuda S, et al. Remote ischemic preconditioning reduces contrast-induced acute kidney injury in patients with ST-elevation myocardial infarction: a randomized controlled trial. Int J Cardiol. 2015 Jan;178:136-41.

33 Zagidullin NS, Dunayeva AR, Plechev VV, Gilmanov AZ, Zagidullin SZ, Er F, et al. Nephroprotective effects of remote ischemic preconditioning in coronary angiography. Clin Hemorheol Microcirc. 2017;65(3):299-307.

34 Zhou F, Song W, Wang Z, Yin L, Yang S, Yang F, et al. Effects of remote ischemic preconditioning on contrast induced nephropathy after percutaneous coronary intervention in patients with acute coronary syndrome. Medicine (Baltimore). 2018 Jan; 97(2):e9579.

35 Roubille F, Macia JC, Ivanes F, Angoulvant D, Mateus V, Belle L, et al. Effects of remote ischemic conditioning on kidney injury in at-risk patients undergoing elective coronary angiography (PREPARE study): a multicenter, randomized clinical trial. Sci Rep. 2019 Aug;9(1):11985.

36 Sendeski MM. Pathophysiology of renal tissue damage by iodinated contrast media. Clin Exp Pharmacol Physiol. 2011 May;38(5):292-9.

37 Evans RG, Ince C, Joles JA, Smith DW, May CN, O'Connor PM, et al. Haemodynamic influences on kidney oxygenation: clinical implications of integrative physiology. Clin Exp Pharmacol Physiol. 2013 Feb;40(2):106-22.

38 Persson PB, Hansell P, Liss P. Pathophysiology of contrast medium-induced nephropathy. Kidney Int. 2005 Jul; 68(1):14-22.

39 Pisani A, Riccio E, Andreucci M, Faga T, Ashour M, Di Nuzzi A, et al. Role of reactive oxygen species in pathogenesis of radiocontrast-induced nephropathy. BioMed Res Int. 2013;2013:868321.

40 Wang X, Kong N, Zhou C, Mungun D, Iyan Z, Guo Y, et al. Effect of Remote Ischemic Preconditioning on Perioperative Cardiac Events in Patients Undergoing Elective Percutaneous Coronary Intervention: A Meta-Analysis of 16 Randomized Trials. Cardiol Res Pract. 2017;2017:6907167.

41 Ravingerova T, Farkasova V, Griecsova L, Carnicka S, Murarikova M, Barlaka E, et al. Remote preconditioning as a novel "conditioning" approach to repair the broken heart: potential mechanisms and clinical applications. Physiol Res. 2016 Sep; 65 Suppl 1:S55-64. 
42 Heusch G, Bøtker HE, Przyklenk K, Redington A, Yellon D. Remote ischemic conditioning. J Am Coll Cardiol. 2015 Jan;65(2):177-95.

43 Veighey K, MacAllister R. Clinical applications of remote ischaemic preconditioning in native and transplant acute kidney injury. Pediatr Nephrol. 2015 Oct;30(10):1749-59.

44 Zagidullin N, Scherbakova E, Safina Y, Zulkarneev R, Zagidullin S. The Impact of Remote Ischemic Preconditioning on Arterial Stiffness and Heart Rate Variability in Patients with Angina Pectoris. J Clin Med. 2016 Jun; $5(7): 5$.

45 Wang F, Yin J, Lu Z, Zhang G, Li J, Xing T, et al. Limb ischemic preconditioning protects against contrast-induced nephropathy via renalase. EBioMedicine. 2016 Jul; 9:356-65.

46 Dharnidharka VR, Kwon C, Stevens G. Serum cystatin C is superior to serum creatinine as a marker of kidney function: a meta-analysis. Am J Kidney Dis. 2002 Aug;40(2):221-6.

47 Laterza OF, Price CP, Scott MG. Cystatin C: an improved estimator of glomerular filtration rate? Clin Chem. 2002 May;48(5):699-707.

48 Devarajan P. Review: neutrophil gelatinase-associated lipocalin: a troponin-like biomarker for human acute kidney injury. Nephrology (Carlton). 2010 Jun;15(4):419-28.

49 Yeung AC, Morozov A, Robertson FP, Fuller BJ, Davidson BR. Neutrophil Gelatinase-Associated Lipocalin (NGAL) in predicting acute kidney injury following orthotopic liver transplantation: A systematic review. Int J Surg. 2018 Nov;59:48-54.

50 Bei WJ, Duan CY, Chen JY, Wang K, Liu YH, Liu Y, et al. Remote Ischemic Conditioning for Preventing ContrastInduced Acute Kidney Injury in Patients Undergoing Percutaneous Coronary Interventions/Coronary Angiography: A Meta-Analysis of Randomized Controlled Trials. J Cardiovasc Pharmacol Ther. 2016 Jan;21(1):53-63.

$51 \mathrm{Hu}$ J, Liu S, Jia P, Xu X, Song N, Zhang T, et al. Protection of remote ischemic preconditioning against acute kidney injury: a systematic review and meta-analysis. Crit Care. 2016 Apr;20(1):111. 